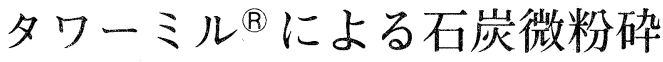 \\ (キーワード 石炭, CWM製造, 微粉砕, 媒体攪䢁形ミル)
}

-1990.6 .20 受理一

\section{1.はじめに}

石炭の有効利用のための粉砕操作には，CW $\mathrm{M}$ 用の湿式粉砕機や微粉炭燃焼用の乾式粉砕機 等, 従来からボールミルが使用されて来た。し かし利用技術が改良進歩し製品粒子の微粉化や 設備の経済性が追及されると共に新しい粉砕技 術の導入が見られるようになった。

タワーミルは媒体攪挥形ミルで，ボールミル に比較して粉砕物の微粉化・運転の経済性など で優れた特徵を持つ粉砕機として, 非鉄金属鉱 山用選鉱設備や排煙脱硫・中和設備に多用され てきたが，ミルの持つ微粉砕特性から石炭微粉 砕用の分野でも使用されるようになった。ここ でタワーミルによる石炭微粉砕技術の概要を紹 介する。

\section{2. タワーミルの構造概要}

タワーミルは日本タワーミル（株）[平成 2 年 4 月クボタタワーミル (株) に社名変更]で 開発された独自技術の粉砕機である。

装置の概要は，駆動モー夕を取付けた上部 ケーシングと円筒状の塔本体が基礎面上に設置 されている。塔本体内部には駆動モー夕に連結 されたスクリュが懸垂されており, 塔本体下部 には圧力流体が流入するように，湿式ではスラ リーポンプ, 乾式ではターボファンが接続され ている。塔内部には, 粉砕媒体となるボールが 充填され，スクリュの回転によってボールは攪 拌転動し投入された石炭を微粉砕する。湿式の

技術部 千葉県柏市大青田字八両野719-1
クボタタワーミル株式会社 藤 岡 完 造

場合下部ノズルを経てスラリーポンプから圧送 された流体は塔内に上昇流を作りだし所定のサ イズに微粉砕された石炭スラリーを上部に持ち

上げ機械から流出させる。

タワーミルでは, 塔本体は静止したままで, 内部に充填されたボールだけが攪找転動する。 しかもスクリュの回転は低速のためボールミル に比べて動力消費の小さい粉砕機構となる。ま たスクリュの回転で攪拌転動されるボールは塔 本体内に充填された状態のためボール同志が跳 びはねたり激しく衝突する事は殆ど無く，また ボールミルのような落下衝撃作用は無い。この ため塔本体内に投入された石炭はボールの摩砕 作用によって効率よく微粉砕される。

\section{CWM用湿式タワーミル}

CWM (Coal Water Mixture) を石油代替燃 料として考える場合, 高濃度化性や静置安定性 等スラリー特性が重要であることは言うまでも ない。石炭を微粉砕する際の粉砕機の粉砕濃度 や粒度分布等の粉砕特性はスラリー特性に大き く影響し, 設備コスト等の経済性にも大きく影 響する。

タワーミルは（株）クボタが開発してきた石 炭スラリー製造技術の中で, 小形試験設備や実 証設備の石炭微粉砕機として使用されてきた。 ここにその実績の一端を紹介する。

\section{1 試験用タワーミルの概要}

試験用タワーミルは運転状況を可変にできる よう，モータやスラリーポンプ等は標準形式を 
一部変更している。粉砕機の概略仕様は下記の 通りである。

3.1 .1 小形試験設備用タワーミル 形式 $\mathrm{KW}-5$

使用モー夕 $11 \mathrm{k} \mathrm{W}$

スクリュ径 $\quad 240 \mathrm{~m} \mathrm{~m}$

機械高さ

$5200 \mathrm{~m} \mathrm{~m}$

投入ボール量 $\quad 600 \mathrm{k} \mathrm{g}$

3.1 .2 実証設備用中形タワーミル

$$
\text { No. } 1 \text { ミル №. } 2 \text { ミル }
$$

形式 $\quad \mathrm{KW}-2000 \mathrm{KW}-250$

使用モ一夕 $150 \mathrm{~kW} \quad 190 \mathrm{~kW}$

スクリュ径 $990 \mathrm{~mm} \quad 990 \mathrm{~m} \mathrm{~m}$

機械高さ 約 $11 \mathrm{~m}$ 約 $11 \mathrm{~m}$

投入ボール量 13 ton 15 ton

Fig. 1 に機械の概略構造を, Fig. 2 に C W M 製造設備のフローシートを示す。

\section{2 タワーミルによる石炭微粉砕}

タワーミルに供給された石炭の性状を Table 1 に示す。Fig. 2 フローシートに示すように， $\mathrm{CWM}$ 製造設備に受け入れた原料の石炭は，夕 ワーミルでの粉砕効率を高めるように湿式ロッ ドミルで粗粉砕される。タワーミルに供給され る原料石炭およびタワーミル粉砕産物の粒度分 布をFig. 3 に示す。この試験では 2 台の夕 ワーミルを直列に使用した 2 段粉砕方式として いるが，実用設備の場合容量の大きい夕ワーミ ル 1 台で同等の粉砕仕事を行うことも可能であ る。石炭スラリーの高濃度化性や静置安定性は 石炭の銘柄で微妙に異なるため, スラリー特性 に関連するタワーミル粉砕産物の粒度分布や添
加剂の添加状況等を銘柄毎に確認する必要があ る。試験操業ではー $1 \mathrm{~m} \mathrm{~m}$ の石炭をタワーミル に供給し、 $-75 \mu \mathrm{m} 87 \%$ 程度に粉砕した場合,

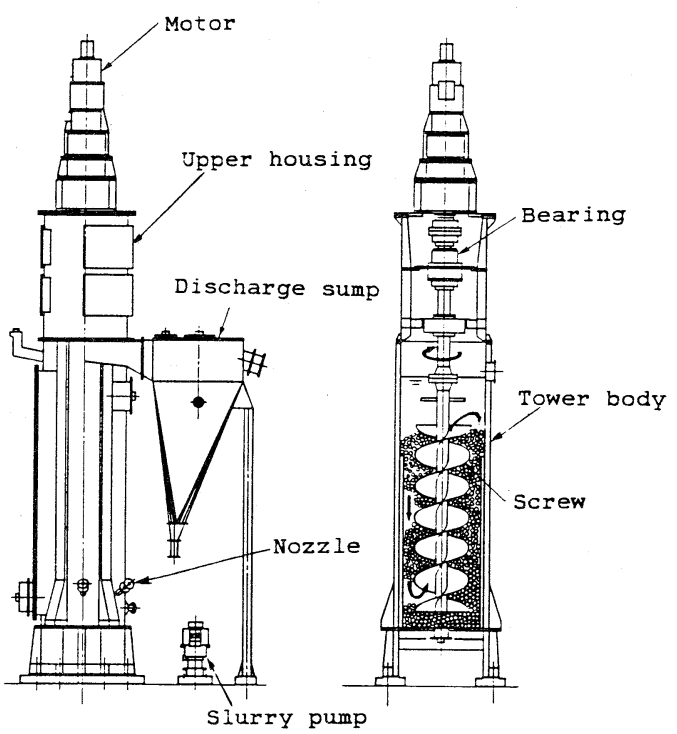

Fig. 1 Tower Mill

Table 1 石炭の性状

\begin{tabular}{|c|c|c|c|}
\hline 項 & \multicolumn{3}{|c|}{ 石炭の性 状 } \\
\hline 銘 & I & II & III \\
\hline 比 & 1.21 & 1.22 & 1.25 \\
\hline 分 析 值 & & & \\
\hline 固有水分 $(\%)$ & 3.3 & 3.5 & 2.0 \\
\hline 分(\%) & 7.2 & 10.0 & 12.8 \\
\hline 揮 発 分(\%) & 34.3 & 27.6 & 21.7 \\
\hline 固定炭素(\%) & 55.2 & 58.9 & 63.5 \\
\hline $\begin{array}{lll}H & G & I\end{array}$ & 43 & 55 & 70 \\
\hline
\end{tabular}

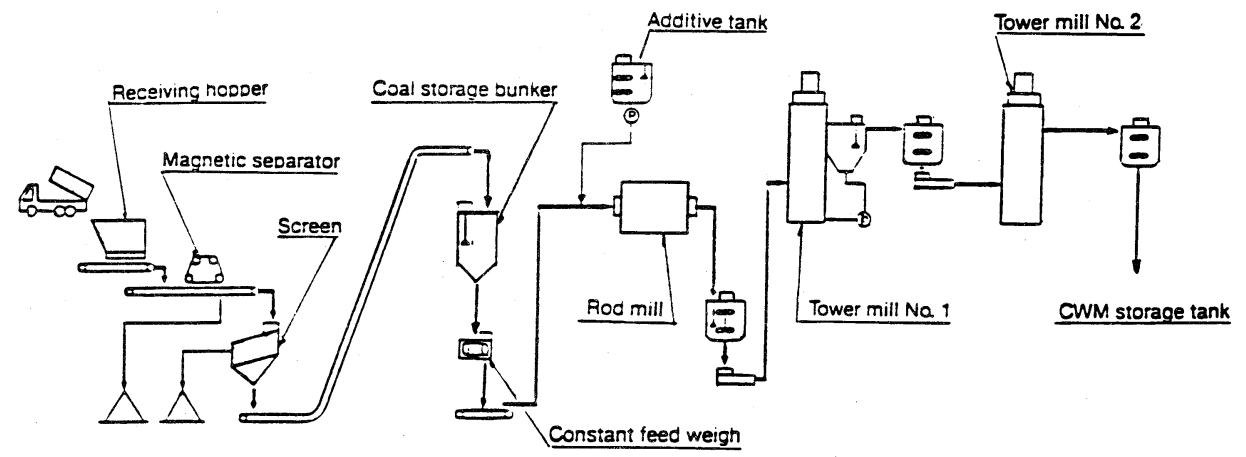

Fig. 2 Flow sheet for CWM plant 


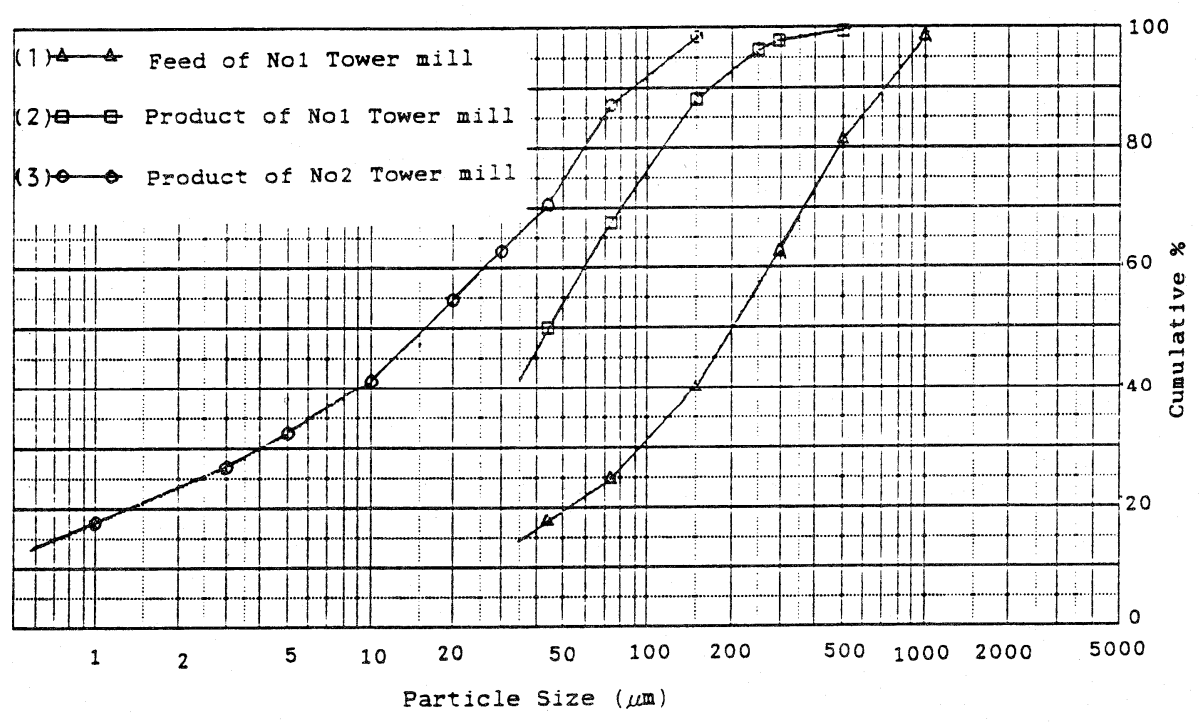

Fig. 3 Particle size distribution

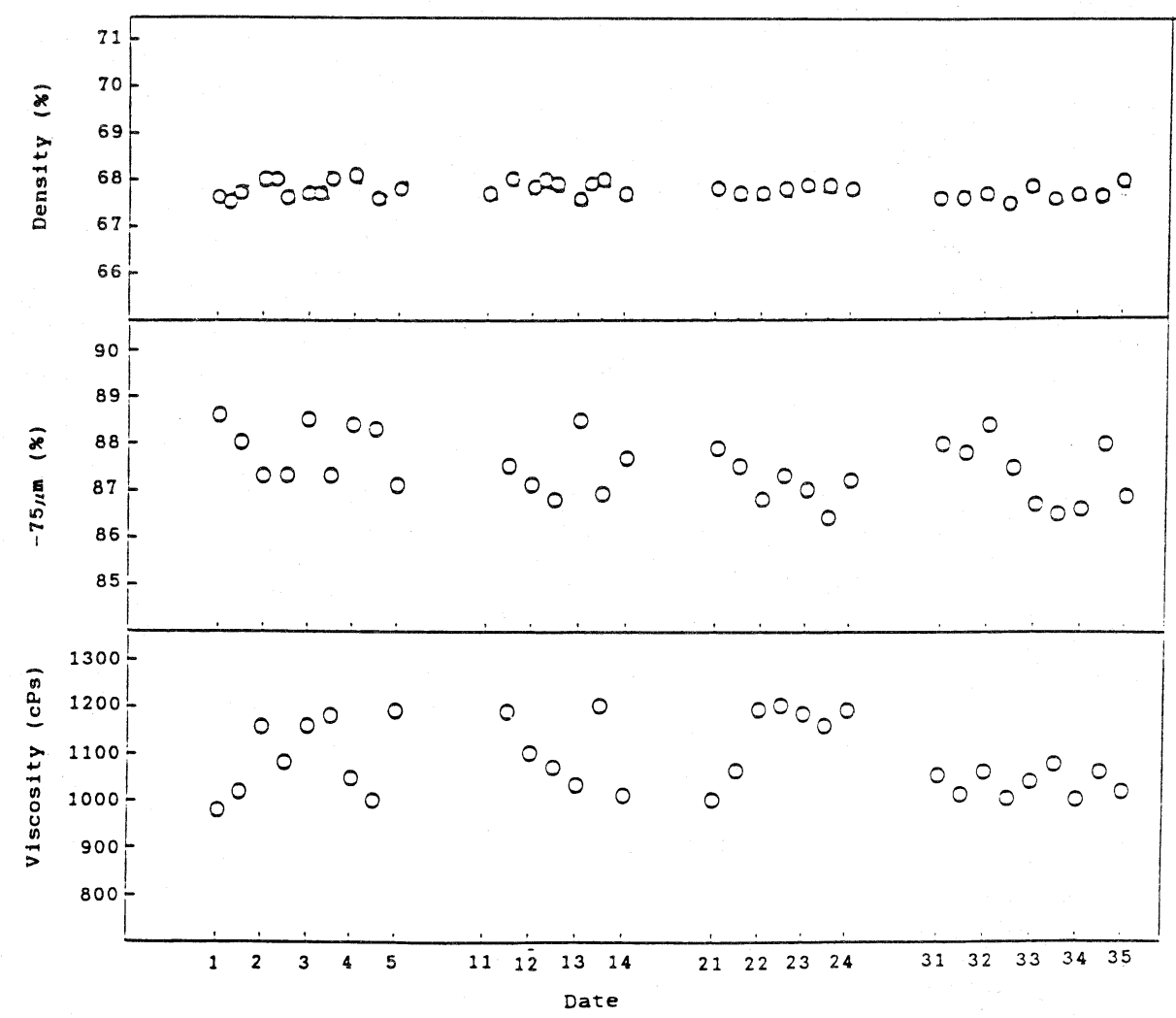

Fig. 4 Operation data of CWM plant 
石炭スラリーの濃度は $68 \%$, 粘度は $1000 \mathrm{cPs}$ で あった。

$\mathrm{CWM}$ 製造設備では, 装置の連続運転に際し て石炭スラリーの各種性状の変動が少なく, 安 定した操業が出来ることも重要な要素である。

Fig. 4 に, 試験操業における連続粉砕操作の状 況を示す。装置の連続運転の為の主要制御項目 はスラリー濃度, スラリー粘度㧍よび固形物粒 度である。石炭スラリー性状の変動割合は, 各 制御項目の中心值に対して, スラリー濃度で士 $0.2 \sim 0.5 \%$ ，スラリー粘度で $\pm 100 \sim 200 \mathrm{cPs}$, 固形物粒度で $\pm 0.5 \sim 1.0 \%$ あ゙る。したがって この連続粉砕操作状況は非常に安定した運転が 行えることを示している。

一般に, タワーミルでは粉砕仕事量を変える と粉砕産物の粒度分布が变わる。粉砕産物の粒 度は石炭スラリーの性状に対応して選定される が, この時のミルの能力と粉砕産物の粒度の関 係をFig. 5 に示す。Fig. 6 は原料石炭の H G I と粉砕動力原単位の関係を示している。Fig. 6 の粉砕動力原単位はロッドミルも含めた粉砕

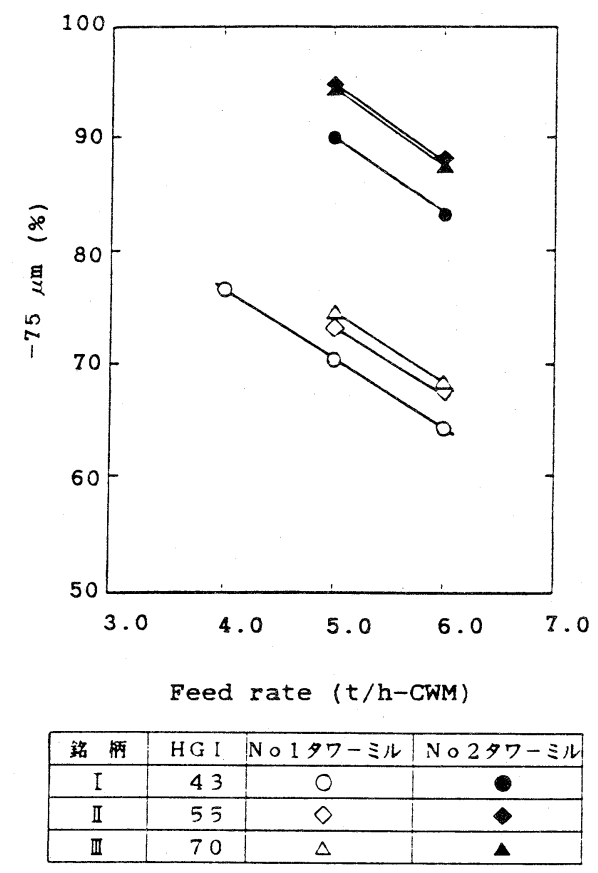

Fig. 5 Tower Mill products

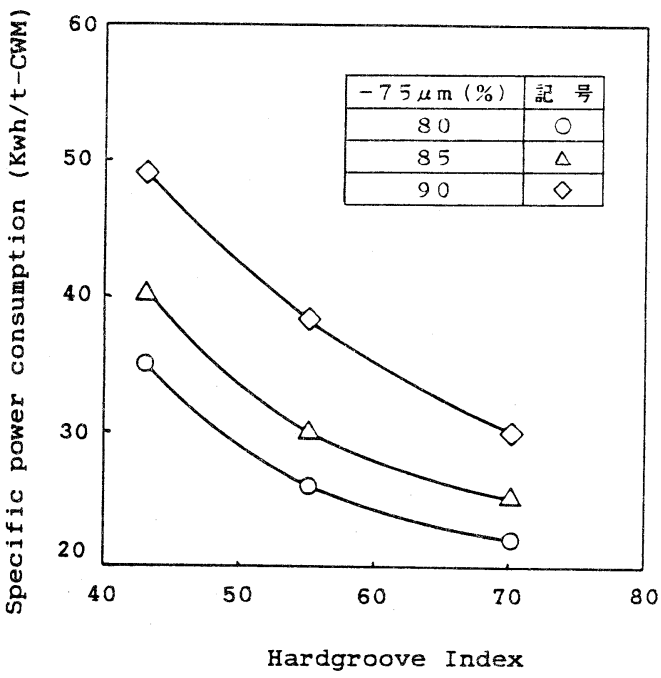

Fig. $6 \mathrm{HGl}$ vs power consumption

機全体の数値であり, タワーミルはこの值の約 75 80\%の所要原単位であり H G I = 50の場合 25 30 kWh/t - CWMであった。

試験操業では約 3300 時間の長期安定運転が行 われた。試験終了後に計測された粉砕ボールの 消耗量は, 2 台のミルの合計で約 $130 \mathrm{~g} / \mathrm{ton}-$ CWMであった。従って石炭の性状変化を考虑 してボールの平均消耗量は100１50 g/ton－ CWM と考えられる。

\section{4. あとがき}

石炭の有効利用のための微粉砕操作としては 前述の湿式粉砕以外にも乾式微粉砕用夕ワーミ ルがある。乾式微粉砕の場合微粉石炭の用途に 応じて, 粉砕産物粒度は $44 \mu \mathrm{m}$ 以下から更に 10 $\mu \mathrm{m}$ 以下の微粉砕のものまで可能である。

本稿では C W M 用湿式タワーミルについて実 績デー夕を報告したが, これらのデー夕は財団 法人石炭技術研究所昭和 63 年度石炭利用技術振 興補助事業の「石炭スラリー技術に関する研 究」の試験研究成果報告書で発表報告したもの を引用した。CWM用の石炭湿式微粉砕につい ては, 石炭の銘柄, 性状によって粉砕特性が変 わるため実機レベルでの検討の際はその都度個 別に実証確認が必要である。 


\title{
Fine Grinding of Coal by TOWER MILL
}

\author{
Kanzo FUJIOKA
}

(Technical Dept. KUBOTA TOWER MILL Corp.)

SYNOPSIS :- Concerning to development and commercialization of CWM (Coal Water Mixture), grinding technology aim to fine grinding. In the demonstrative CWM plant furnished by KUBOTA Corp., TOWER MILLs are main functional component of fine grinding unit.

TOWER MILL invented originally by Kubota Tower Mill Corp. (called "Japan Tower Mill Co., Ltd." in former days) consists of vertical cylindrical body like as TOWER and rotating Screw. These components work like as Stirred type ball mill and can achieve fine grinding of materials. Result of the demonstrative operation of CWM plant was very successful. TOWER MILL ground coal from $1 \mathrm{~mm}$ particle size to $87 \%$ through 75 microns for product, and produced CWM slurry with $68 \%$ density and $1000 \mathrm{cps}$ viscosity. Specific power consumption for TOWER MILL was 25$30 \mathrm{kWh} / \mathrm{t}-\mathrm{CWM}$.

\section{Key Words}

CWM, Fine grinding, Mill

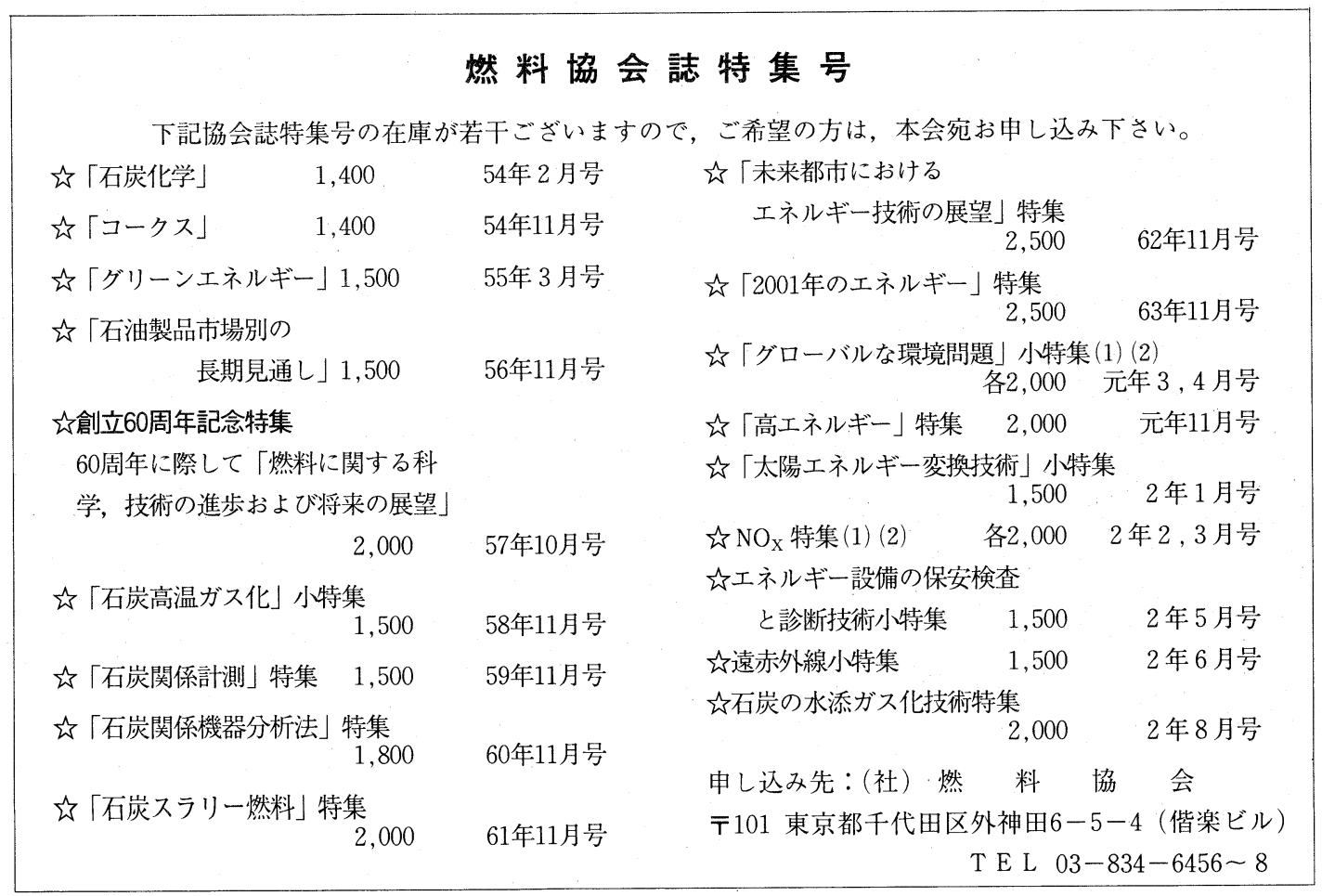

